Annisa B Tribhuwaneswari, Anindita Ramadhani, dan Rizky Darmadi: Pengaruh Faktor Place Attachment Pada Proses Adaptasi Habitat Di Permukiman Petemon, Surabaya

\title{
PENGARUH FAKTOR PLACE ATTACHMENT PADA PROSES ADAPTASI HABITAT DI PERMUKIMAN PETEMON, SURABAYA
}

\author{
Annisa B Tribhuwaneswari ${ }^{1 *}$, Anindita Ramadhani², Rizky Darmadi ${ }^{3}$ \\ ${ }^{1 *}$ Program Studi Perencanaan Wilayah dan Kota, Fakultas Teknik Sipil dan Perencanaan, \\ Universitas PGRI Adi Buana, Surabaya, 60234,Indonesia \\ ${ }^{2}$ Perencanaan Wilayah dan Kota, Fakultas Arsitektur Lanskap dan Teknologi Lingkungan, \\ Universitas Trisakti, Jakarta, 11450, Indonesia \\ ${ }^{3}$ Arsitektur, Institut Teknologi Sepuluh Nopember, Surabaya, Jawa Timur \\ Email: annisab.t@unipasby.ac.id
}

\begin{abstract}
Abstrak
Proses adaptasi habitat merupakan cerminan adanya faktor keterikatan masyarakat terhadap suatu kawasan kota, yang dipengaruhi oleh faktor fisik dan non fisik. Permukiman Petemon merupakan permukiman yang berumur cukup tua di kota Surabaya. Kawasan ini dikenal pula sebagai kawasan yang terdampak cukup berat ketika musim hujan di Surabaya dikarenakan banjir. Namun, berdasarkan data profil kependudukan kelurahan Petemon, terjadi peningkatan jumlah penduduk dari tahun 2014-2016 dari dari 291 jiwa/hektare menjadi 306 jiwa/hektare. Hal ini terjadi dikarenakan adanya proses adaptasi habitat pada cara bermukim masyarakat akibat keberadaan faktor keterikatan yang menjadi penyebab bertahannya penguni di kawasan permukiman Petemon. Maka, diperlukan kajian terkait faktor place attachment yang terjadi pada kawasan permukiman ini yang menyebabkan proses adaptasi habitat. Tujuan dari penelitian ini adalah untuk mengidentifikasi faktor place attachment dalam adaptasi habitat di Permukiman Petemon. Metode penelitian yang digunakan adalah deskriptif kualitatif, dengan teknik analisa dengan teknik analisis character appraisal dalam menilai dan mengelompokkan lingkungan permukiman serta metode wawancara dan pengamatan untuk menngidentifkasikan faktornya. Hasil dari penelitian ini adalah teridentifikasinya faktor place attachment pada kawasan studi. Faktor place attachment yang teridentifikasi adalah faktor fisik, sosial, kultural, individu, pengalaman, fasilitas sosial, kepuasan akan suatu tempat.
\end{abstract}

Kata Kunci : adaptasi habitat, banjir, kampung, kawasan permukiman, place attachment

\begin{abstract}
The habitat selection process is a reflection of the existence of a factor of community attachment to a city area, which is influenced by physical and non-physical factors. Petemon settlement is a fairly old-age comunity in the city of Surabaya. This area is also known as the area that was affected quite heavily during the rainy season in Surabaya due to flooding. However, based on the population profile data of the Petemon village, there was an increase in the population from 2014-2016 from 291 people / hectare to 306 people / hectare. This happened because of the habitat adaptation process in the way of settling the community due to the existence of attachment factors which were the cause of the inhabitants' persistence in the Petemon residential area. Thus, a study is needed regarding the place attachment factor that occurs in this residential area which causes a process of habitat adaptation. The purpose of this study was to identify place attachment factors in habitat adaptation at Petemon Settlement. The research method used is descriptive qualitative, with character appraisal analysis techniques to assess and classify residential environments as well as interview and observation methods to identify the factors. The results of this study are identification of place attachment factors in the study area.
\end{abstract}


Annisa B Tribhuwaneswari, Anindita Ramadhani, dan Rizky Darmadi: Pengaruh Faktor Place Attachment Pada Proses Adaptasi Habitat Di Permukiman Petemon, Surabaya

The place attachment factor identified is physical, social, cultural, individual, experience, social facilities, satisfaction with a place.

Keywords: habitat selection, flood, village, settlement area, place attachment

\section{PENDAHULUAN}

Kota terdiri dari kumpulan area yang mengekspresikan identitas sosial, status dan pilihan berbagai kelompok. Keputusan yang dikaitkan dengan lingkungan, termasuk perpindahan penduduknya, setidaknya mampu mengekspresikan pilihan yang tidak dapat dielakkan dari kelompok terkait (Rapoport, 2018). Pola perilaku suatu komunitas tertentu dalam menciptakan keseimbangan yang menyeluruh terhadap pola kehidupan dan penghidupannya akan menimbulkan ikatan/pertalian emosi (community attachment) antara manusia penghuni dengan tempat tinggalnya sesuai dengan persepsi dan kognisi masing-masing individu. Hashemnezhad (2013), menuliskan bahwa "tempat" adalah suatu ruang yang memiliki makna tertentu bagi penghuni atau penggunanya. Konsep "tempat" (place) didasarkan pada interaksi antara seseorang, setting fisik, dan aktivitas yang terjadi pada lokasi tersebut. Konsep ruang seketika berubah sesuai pola bagaimana manusia memberikan pemahaman makna baik melalui aktivitas sehari-hari atau dengan tradisi sosial yang dikerjakan secara rutin pada tempat tersebut.
Kota Surabaya dimaknai sebagai bagian yang terdiri dari kantong - kantong permukiman (kampung) yang berdiri mengisi bagian wilayah kota (Silas, 2013). Beberapa ruang kota tersebut mengalami perkembangan sejalan dengan upaya pemerintah mengembangkan infrastruktur kota baik berupa permukiman dan saran pendukung lainnya. Menilik perkembangan pemukiman paling lama di Surabaya, diantaranya dapat ditemukan cukup banyak pada kawasan Unit Pengembangan Wonokromo. Kawasan Wonokromo tumbuh setelah upaya Pemerintah Geementee (Hindia Belanda) memindahkan pusat pemerintahan dari semula di daerah jembatan merah menuju kawasan UP. Tunjungan.

Petemon merupakan salah satu permukiman pada kawasan Wonokromo yang berada di kecamatan Sawahan seperti peta yang tertera pada gambar 1 dibawah ini. Kawasan tersebut diidentifikasi sebagai kawasan permukiman yang sangat padat dengan fungsi intensitas permukiman cukup tinggi dengan jumlah populasi tertinggi di tahun 2006 sebesar 216.316 jiwa (Katherina, 2017). 


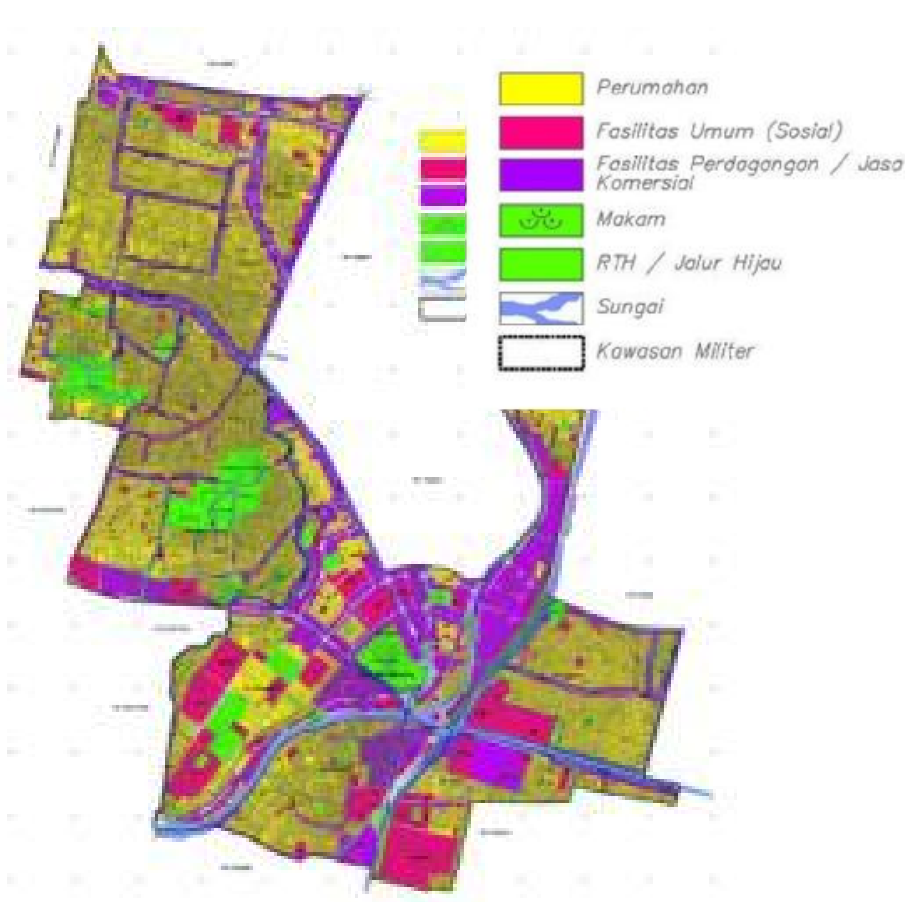

Gambar 1. Peta Lokasi Penelitian Permukiman Petemon ditinjau dari Kawasan UP. Wonokromo

Ketidakberadaan ruang terbuka umum yang cukup luas, menyebabkan fungsi ekologis ruang menjadi tidak berjalan baik. Padatnya permukiman menjadikan fungsi utama vegetasi untuk menangkap air menjadi hilang. Fakta pembangunan yang tidak memperhatikan ekologis menjadikan ruang permukiman menjadi sangat rawan akan banjir apabila terjadi hujan. Namun diketahui, dalam hal non fisik, kekuatan partisipasi masyarakat dalam hal ekonomi cukup terwadahi. Dengan menjadi kampung produktif pembuat bahan makanan (lontong) dan lamanya kebertahanan penduduk terhadap masalah yang cukup banyak tersebut membuat komunitas Kampung Petemon memiliki "place attachment" cukup kuat.

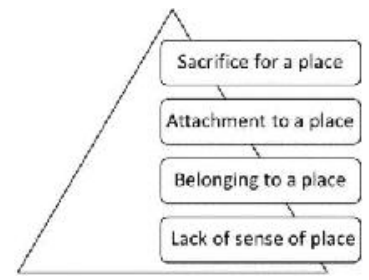

Gambar 2. Tahapan Keterikatan Terhadap Tempat

Place Attachment sendiri dikenali sebagai fenomena yang kompleks menjadi suatu peluang untuk dijabarkan dalam berbagai macam tipe dengan aspek, asalusul dan tujuan yang. Place Attachment memberikan kontribusi terhadap formasipemeliharaan-preservasi terhadap identitas individu, kelompok ataupun budaya (Hashemnezhad et al, 2013). Pada gambar 2 dapat dilihat bahwa place attachment 
memiliki beberapa tingkatan, hierarki yang tertinggi dikenali dengan sacrifice for a place, dimana masyarakat memiliki sense of place yang sangat tinggi hingga berkomitmen yang membuat mereka rela mengorbankan atribut penting dan nilai nilai seperti kesejahteraan, kebebasan, dan kehidupan itu sendiri (Stedman RC, 2003). Identifikasi tingkatan place attachment dapat dikenali melalui kajian akan keberadaan semua faktor yang mendorong maupun yang menarik manusia untuk bermukim dan menempati suatu wilayah (push and pull factors). Faktor - faktor tersebut diantaranya adalah, faktor fisik, sosial, kultural, individu, pengalaman, fasilitas sosial, kepuasan akan suatu tempat (Newell, 2018).Berbagai fenomena yang terjadi di kawasan permukiman Petemon menjadi dasar kawasan ini dipilih menjadi lokasi studi serta menarik untuk dianalisa

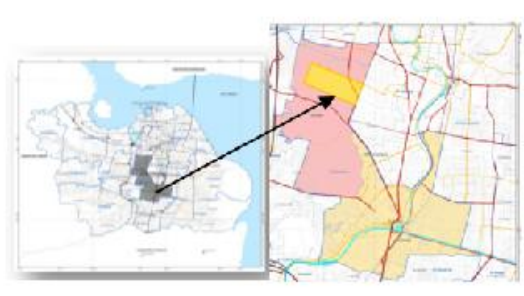

Gambar 3. Peta Lokasi Penelitian Permukiman Petemon ditinjau dari Kota Surabaya

Pada gambar 3 dapat dilihat bahwa posisi permukiman yang cukup strategis dikarenakan letaknya yang berdekatan dengan pintu gerbang utama masuk ke kota Surabaya dari arah selatan dan utara, serta memiliki kondisi aksesibilitas yang baik,. Kondisi lalu lintas yang sangat padat dikarenakan akses jalan Banyu Urip yang berada tepat di selatan lingkup penelitian merupakan saluran kolektor primer. Selain itu, pemerintah juga telah membangun flyover guna mengatasi kemacetan dari Timur ke Barat.

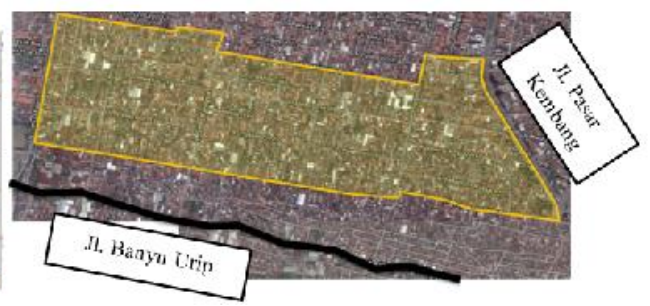

lebih lanjut mengenai "Place Attachment", dengan mengungkap budaya bermukim masyarakat yang tinggal pada masa sekarang dan adanya konsep hunian berdasarkan sudut pandang perilaku berhuni pola adaptasi dan budaya bermukim pada kawasan penelitian.

Ruang lingkup wilayah studi yang dibahas dalam penelitian ini meliputi zona kawasan yang telah ditetapkan sesuai dengan Rencana Detail Tata Ruang Kota Surabaya Unit Pengembangan Kawasan Wonokromo yaitu pada Permukiman Petemon. Permukiman ini berada di UP VII Wonokromo yang memiliki fungsi utama sebagai permukiman, perdagangan dan jasa, serta pertahanan dan keamanan. Wilayah penelitian merupakan area yang memiliki dengan sejarah banjir yang tahunan
Sebagai kawasan permukiman, kawasan studi merupakan kawasan dengan tingkat kerawanan banjir yang cukup intensif di kala hujan turun, akibat topografi daerah Petemon yang lebih rendah dari kawasan di sekitarnya (Husain, 2016). Permasalahan fisik lain diantaranya berupa lalu lintas serta wilayah yang padat oleh tumbuhnya permukiman tanpa ruang terbuka serta titik banjir yang muncul ketika hujan (Zakiyah, 2017). Faktor ini menyebabkan kompleksnya permasalahan pada kawasan. Berdasarkan data 
Annisa B Tribhuwaneswari, Anindita Ramadhani, dan Rizky Darmadi: Pengaruh Faktor Place Attachment Pada Proses Adaptasi Habitat Di Permukiman Petemon, Surabaya

kependudukan Kecamatan Sawahan dari 2014-2016 menunjukkan peningkatan kepadatan penduduk dari 291 jiwa/hektare menjadi 306 jiwa/hektare (Katherina, 2017). Dari beberapa fakta yang terungkap melalui observasi dan wawancara menyebutkan meskipun terjadi ketidaknyamanan dalam berhuni, dapat diidentifikasi bahwa masih terdapat dominasi penduduk asli yang tinggal disana selama beberapa generasi yang membuktikan bahwa fenomena keterkaitan pada tempat sangat mungkin terjadi.

\section{METODE}

Metode penelitian yang digunakan adalah deskriptif kualitatif. Metode ini dipakai untuk mengkaji faktor - faktor dari place attachment yang mengakibatkan adanya proses adaptasi habitat pada Kawasan Permukiman Petemon. Teknik analisis character appraisal digunakan untuk menilai dan mengelompokkan lingkungan permukiman serta penggunaan metode wawancara dan pengamatan untuk menngidentifikasikan faktornya. Analisa dilakukan terhadap standar hunian baru pada kawasan akan menjadi implikasi langsung terhadap upaya penyesuaian yang dilakukan akibat pengaruh banjir tahunan. Faktor place attachment yang diidentifikasi adalah faktor fisik, sosial, kultural, individu, pengalaman, fasilitas sosial, kepuasan akan suatu tempat untuk menilai tingkat place attachment yang terjadi di permukiman Petemon. Habitat selection diindikasikan dari adanya adaptasi standar hunian pada lokasi.

\section{HASIL DAN PEMBAHASAN}

\subsection{Analisis Faktor Fisik}

Faktor fisik yang dimaksud adalah suatu keadaan dimana seseorang sangat mengenali suatu tempat dan mengidentifikasi mengapa hal tersebut sangat berarti baginya. Maka, hal yang diidentifikasi adalah mengenai karakteristik suatu kawasan dan bagaimana fenomena area terbangun yang terbentuk sebagai akibat adanya karakteristik tersebut. Hal ini menimbulkan adanya "place identity", dimana suatu wilayah dianggap memiliki suatu identitas khusus yang melekat pada masyarakat yang tinggal didalamnya serta dikenal luas oleh masyarakat luar.

Pada kawasan studi, Kampung Petemon merupakan kawasan yang ketinggiannya lebih rendah dibanding kawasan sekitarnya. Penggambaran luasan kawasan rawan banjir di Kampung Petemon berdasarkan Surabaya Drainage Master Plan pada gambar 4 diidentifikasikan dengan warna hijau sebagai kawasan tergenang, dimana kawasan Petemon hampir seluruhnya merupakan kawasan rawan banjir. Hal ini menyebabkan kawasan Petemon mudah menerima limpasan air hujan dari kawasan sekitarnya, terutama dari saluran-saluran disekelilingnya yang meluap karena tidak mampu menampung air hujan. Kawasan ini juga menerima limpasan air dari saluran di Jalan Banyu Urip; Perkembangan Jalan Banyu Urip sebagai penghubung kawasan pusat kota - selatan kota menyebabkan padatnya kegiatan maupun volume lalu lintas pada ruas jalan ini, yang secara tidak langsung mempengaruhi daya dukung lingkungannya. 
Annisa B Tribhuwaneswari, Anindita Ramadhani, dan Rizky Darmadi: Pengaruh Faktor Place Attachment Pada Proses Adaptasi Habitat Di Permukiman Petemon, Surabaya

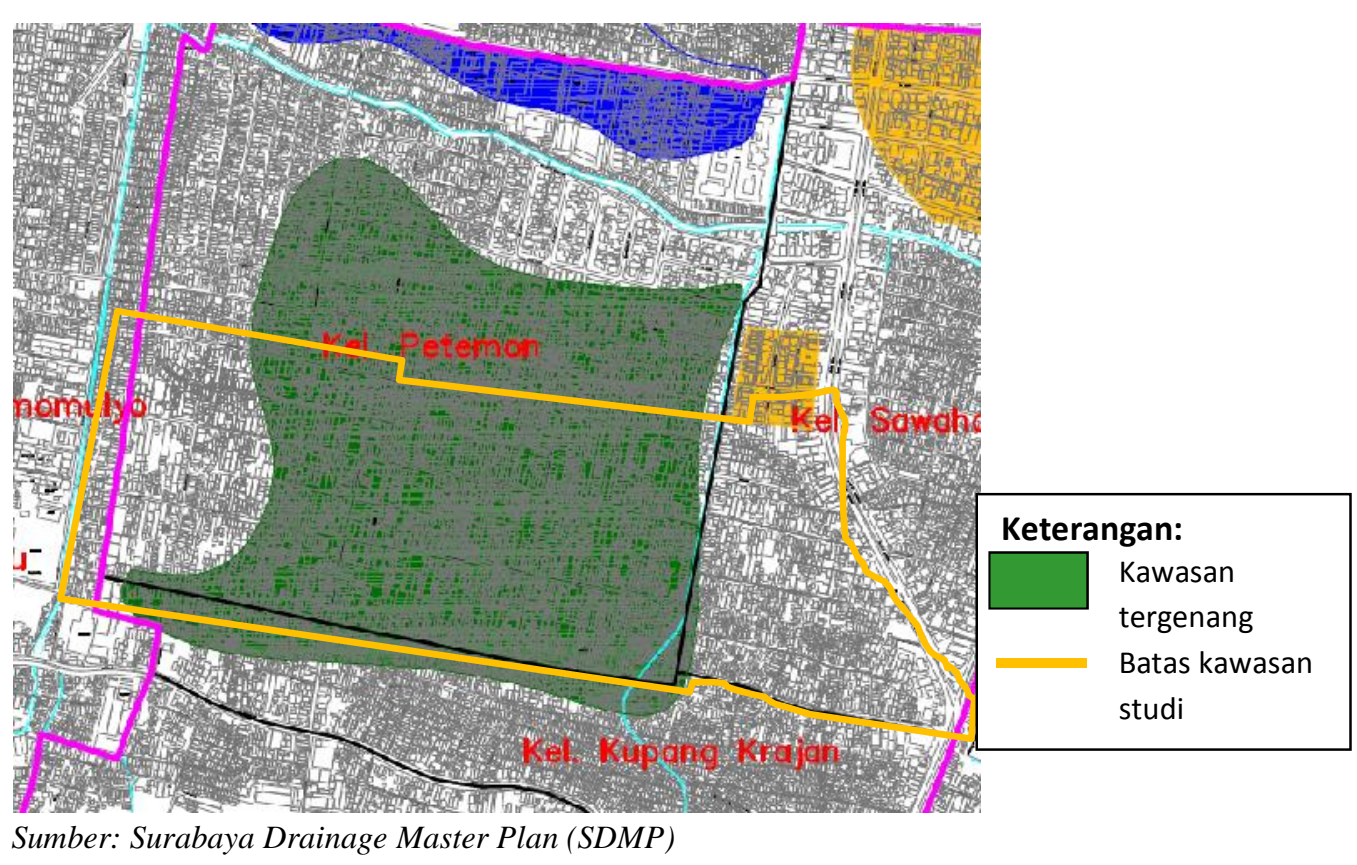

Gambar 4. Kawasan Rawan Bencana Banjir di Kampung Petemon

Kondisi genangan pada kawasan studi terjadi secara menahun dengan ketinggian 10-50 cm dengan jangka waktu genangan hingga 3 jam. Genangan terjadi ketika hujan dengan intensitas tinggi, terutama saat saluran di Jalan Simomulyo dan Petemon Kali meluap, serta limpasan dari Jalan
Banyu Urip. Hal ini dapat dilihat pada gambar 5 dimana titik 1, 2, dan 3 semuanya rata tergenang air hujan. Titik 1 dan 3 di Jalan Petemon 3 dan Jalan Petemon Barat dinilai terdampak cukup berat karena ketinggian air cukup tinggi.

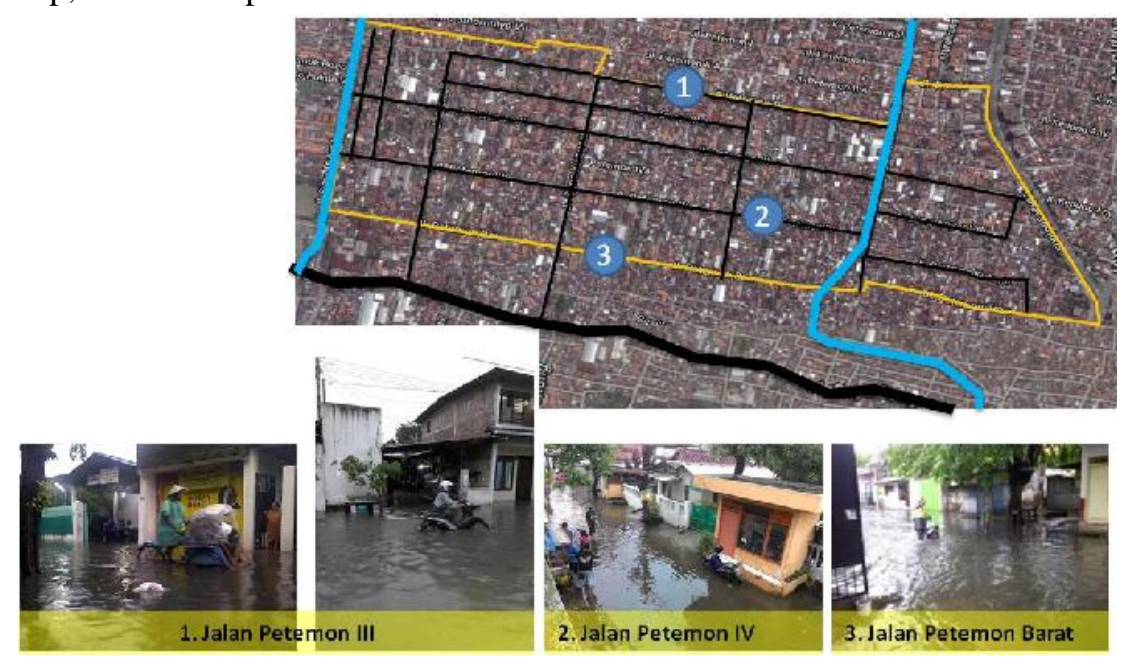

Gambar 5. Banjir Pada beberapa titik di Kawasan Petemon 
Dengan adanya kondisi banjir bagian parkir kendaraan (gambar 6.1, 6.3). menahun tersebut, memberikan dampak pada tipologi bangunan di Kawasan Petemon. Bangunan-bangunan di Kawasan Petemon pada gambar 6 dibawah ini, telah disesuaikan untuk menghadapi banjir. Bangunan rumah maupun perdagangan dan jasa pada kawasan ini telah ditinggikan dari jalan, dengan tangga (undakan) maupun ram. Beberapa bangunan yang tidak ditinggikan memiliki pembatas di pintu masuk untuk menghalau air (gambar 6.3, 6.4, 6.8) yang diindikasikan dengan lingkaran berwarna merah. Sedangkan pada beberapa rumah ditinggikan sebagian pada

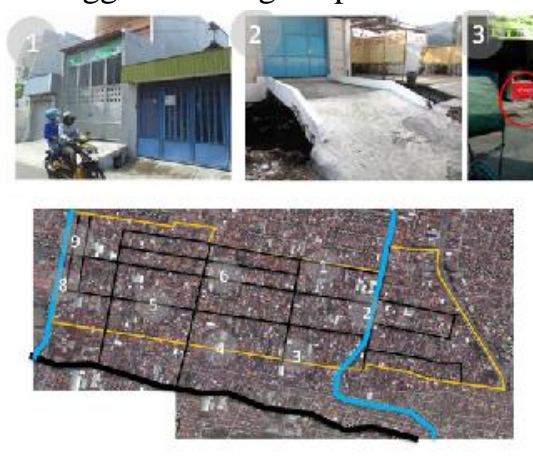
Kawasan ini memiliki metode parkir komunal dengan dua lokasi parkir yang berbeda, namun terdapat persamaan dimana kondisi lapangan parkir memiliki atap dan ketinggian lantai yang cukup tinggi dari jalan (gambar 6.5, 6.6, 6.7). Keberadaan bangunan-bangunan yang telah dimodifikasi ini menandakan adanya upaya masyarakat setempat untuk beradaptasi dengan ketidaknyamanan pada lingkungannya dan menciptakan suatu budaya bermukim khas, daripada memilih pergi meninggalkan lingkungannya.

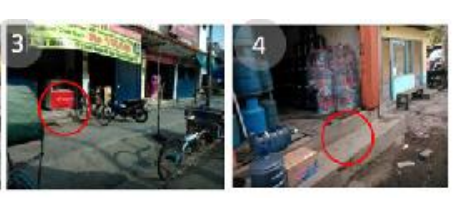

Gambar 6. Tipologi Bangunan di Kawasan Petemon

Kawasan Petemon ini merupakan suatu kawasan permukiman padat, dimana hunian warga langsung berbatasan dengan jalan. Tidak ditemukan ruang luar berupa taman maupun lapangan terkecuali lapangan parkir komunal untuk kendaraan bermotor, serta kurangnya vegetasi pada kawasan. Hal ini menyebabkan munculnya upaya modifikasi ruang untuk mendapatkan lahan yang lebih, yaitu dengan menutup saluran untuk digunakan sebagai jalan maupun tambahan ruang untuk aktivitas warga, misalnya berjualan yang diidentifikasi dengan lingkaran merah pada gambar $7 \mathrm{di}$ bawah ini. 


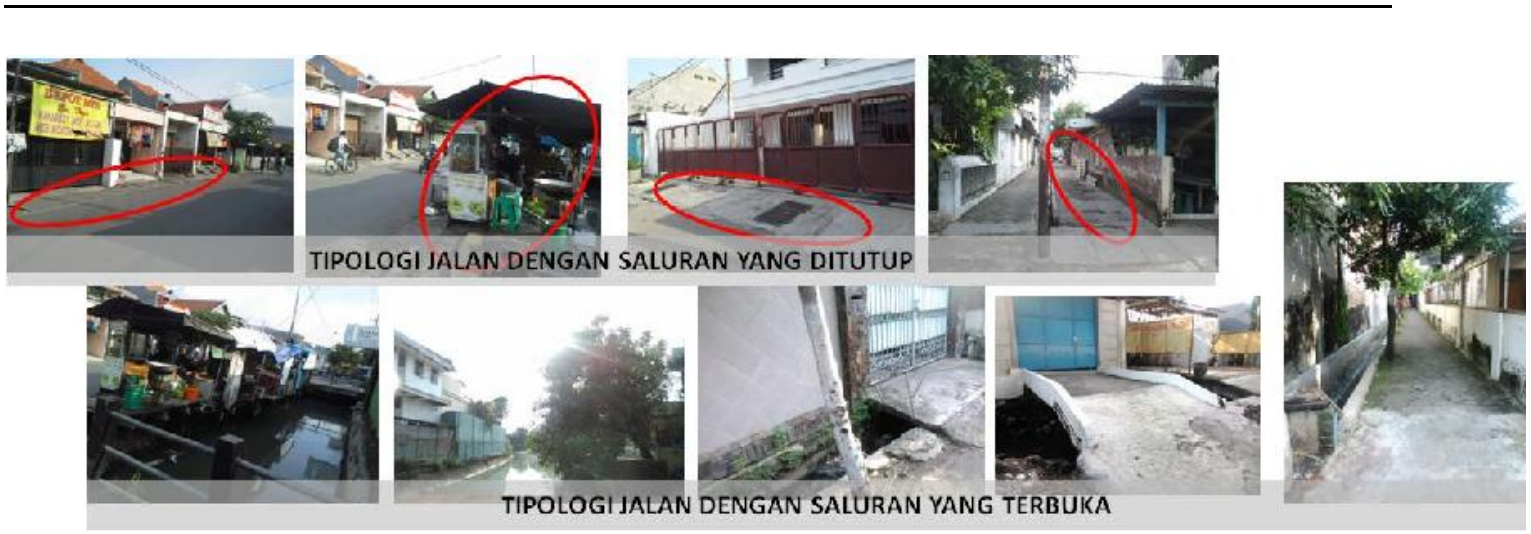

Gambar 7. Tipologi Ruang Luar di Kawasan Petemon

\subsection{Analisis Faktor Sosial}

Lingkungan psikis tidak hanya berhubungan dengan fisik sebuah tempat namun juga menciptakan dimensi sosial. Hubungan yang positif antara tempat dan kepuasan individu berkaitan dengan komunikasi sosial, pengalaman bersosialisasi inilah yang yang berperan dalam memberikan 'makna' tempat terhadap masing - masing individu (Fuad, 2007) .

Pembentukan aktivitas-aktivitas sosial di dalam kampung diakibatkan karena kedekatan antar individu, hal ini disebabkan kedekatan pada lingkungan fisik seperti rumah yang berdekatan, namun juga karena keinginan membentuk suatu ikatan bersama di dalam kampung, dalam hal ini diwakili dengan aktivitas sehari-hari warga permukiman, seperti berkumpul di warung (Gambar 8b), anak-anak bermain serta aktivitas bertetangga warga dengan berkumpul di depan hunian (Gambar 8a). Keeratan sosial dapat dirasakan dari banyaknya persebaran kegiatan bersama warga, ruang luar sebagai tempat bermain anak. Hal ini menandakan adanya rasa aman dan memiliki masyarakat pada kawasan permukiman.
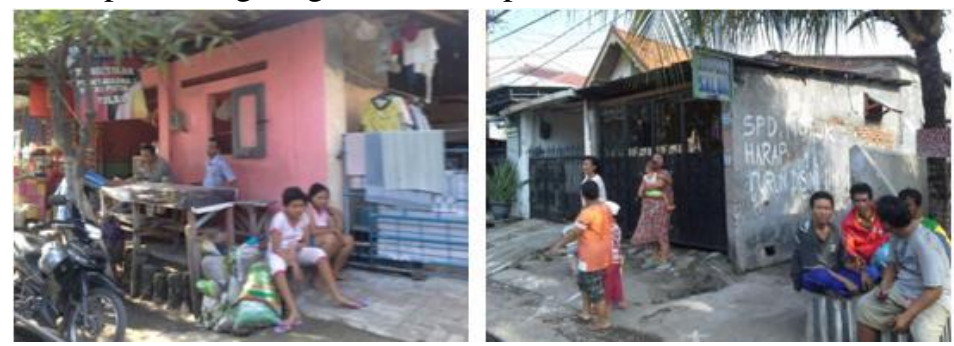

(a)

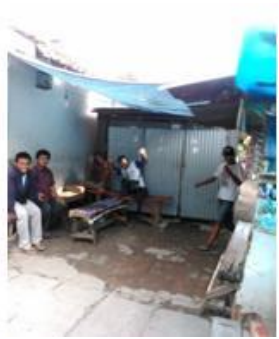

(b)

Gambar 8. Aktivitas sosial anak-anak (a), warga berkumpul (b) di Kawasan Petemon

\subsection{Analisis Faktor Kultural}

Kawasan penelitian merupakan kawasan multietnis dengan percampuran antara pendatang dan penduduk asli. Keberadaan pendatang merupakan konsekuensi dari lokasi kawasan yang strategis dekat dengan pusat kota sehingga mendorong munculnya rumah-rumah kos bagi karyawan yang bekerja di pusat kota Selain itu, banjir menahun juga memaksa beberapa warga yang cukup mampu untuk pergi dan menyewakan rumahnya. 
Walaupun demikian, penduduk asli yang tinggal disana tetap menetap, salah satunya dikarenakan tanah tempat tinggal mereka merupakan warisan dari beberapa generasi. Ciri khas penduduk asli yang sudah melekat hingga memunculkan suatu kampung tematik pada kawasan penelitian, seperti kampung lontong dan kampung tempe.

\subsection{Analisis Faktor Individu}

Keterikatan akan suatu tempat berbeda - beda pada tiap manusianya. Mereka akan memilih dan terikat pada tempat tersebut atas kesadaran masing masing yang disebabkan oleh karakteristik faktor personal. Pada Kawasan Petemon, faktor individu ini juga berperan dalam membentuk keterikatan pada tempat. Dengan berbagai ketidaknyamanan yang ada di kawasan tersebut (banjir, kepadatan bangunan, volume lalu lintas tinggi), menyebabkan beberapa penduduk asli yang memiliki tingkat ekonomi yang lebih tinggi memilih meninggalkan kawasan tersebut. Sebagai gantinya, rumah yang ditinggalkan dikontrakkan atau menjadi rumah kos, mengingat lokasinya yang strategis di tengah kota. Disisi lain, masih banyak penduduk asli yang memilih menetap dari generasi ke generasi dan beradaptasi dengan lingkungan sekitar, salah satunya dengan memperbaiki kawasan permukiman, meninggikan bangunan, dsb.

Berdasarkan hasil wawancara
terdapat berbagai alasan mengenai
bertahannya penduduk asli di Kawasan
Petemon, diantaranya:

a. Keterikatan emosi individu pada tempat melalui memori

Penduduk asli telah menempati kawasan tersebut selama beberapa generasi dan menciptakan memori tersendiri

b. Hubungan kekerabatan yang erat Ikatan kekeluargaan yang erat menumbuhkan rasa saling memiliki dan menjaga sehingga ada kecenderungan untuk selalu berkumpul dengan keluarga di tempat asal

c. Keterikatan hubungan antar individu

Selain hubungan kekerabatan yang erat, hubungan antar warga juga mempengaruhi seseorang untuk bertahan di lingkungan tempat tinggalnya

d. Jarak antar rumah yang berdekatan

Sebagai kampung yang padat penduduk, tentu saja lahan yang tersedia terbatas sehingga jarak antar rumah berdekatan dan membuat interaksi antar individu pun menjadi semakin mudah.

e. Lokasi yang strategis

Kawasan Petemon terletak dekat dengan pusat kota serta memiliki akses yang menghubungkan bagian selatan-barat kota dengan pusat kota

f. Harga lahan yang semakin mahal Harga lahan diperkotaan yang semakin mahal menjadi salah satu alasan mengapa warga Kampung Petemon enggan untuk pindah tempat. 


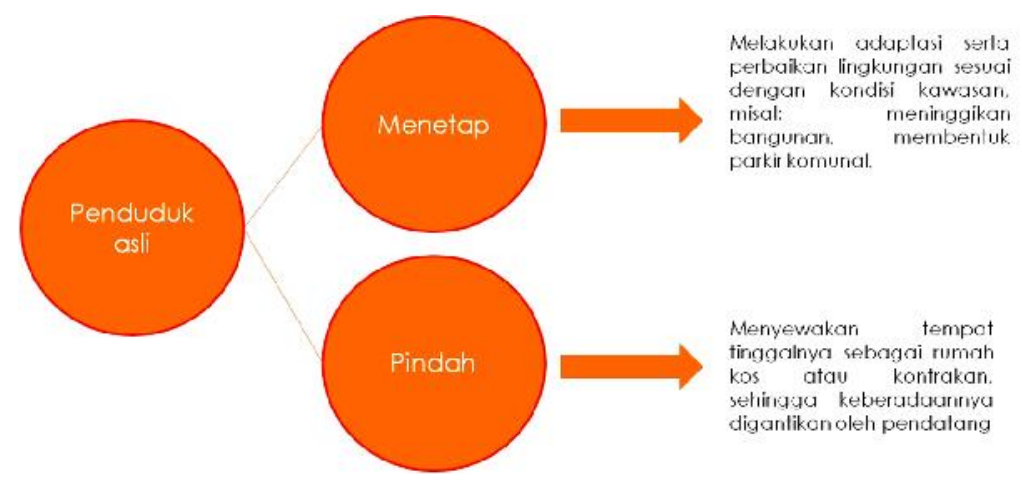

Gambar 9. Bagan Faktor Pilihan Individu di Kawasan Petemon

Melalui gambar 9 dapat dipahami bagwa penduduk asli Petemon tidak menjual hunian, diantaranya ada yang memilih menetap dengan melakukan adaptasi tergadap lingkungannya, maupun menyewakan huniannya ke penduduk yang baru. Sehingga dapat disimpulkan permukiman Petemon memiliki faktor pilihan individu yang cukup kuat dari pergerakan penduduk asli yang telah melalui proses push and pull factors. Berdasarkan data pada tahun 2014 - 2017 permukiman di kelurahan Petemon memiliki peningkatan jumlah penduduk sebesar $0,4 \%$ (diolah dari Kecamatan Sawahan dalam Angka 20142017). Pertumbuhan ini dinilai cukup signifikan mengingat kondisi permukiman Petemon yang kurang ideal dengan adanya bencana banjir tahunan dan kemacetan yang ada.

\subsection{Analisis Faktor Waktu, Memori dan Pengalaman}

Seperti yang telah disebutkan pada pembahasan faktor individu, salah satu alasan warga di Kawasan Petemon masih menetap di kawasan yang sama adalah keterikatan emosi individu pada tempat melalui memori. Hal ini sejalan dengan pernyataan Hidalgo dan Hernandez (2001) yaitu, sebuah tempat yang mengandung place attachment tidak akan dinilai hanya sebagai sebuah 'tempat'; didalamnya terdapat memori masa - masa bermukim, terdapat ikatan antara memori, pengalaman, dan petualangan favorit yang menjadikan tempat itu sebagai sebuah simbol masa kecilnya. Kualitas masa kecil seorang anak akan suatu tempat juga mempengaruhi keterikatan seseorang terhadap tempat tersebut.

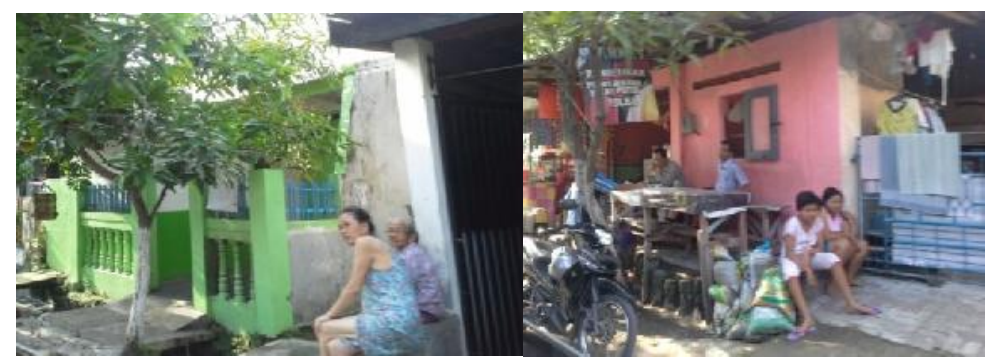

Gambar 10. Masyarakat Lintas Generasi di Kawasan Petemon 
Annisa B Tribhuwaneswari, Anindita Ramadhani, dan Rizky Darmadi: Pengaruh Faktor Place Attachment Pada Proses Adaptasi Habitat Di Permukiman Petemon, Surabaya

Rata-rata lama masa tinggal masyarakat di Kawasan Petemon adalah 20-30 tahun. Hal ini berarti rata-rata penduduk di sana tinggal hingga mencapai 3 generasi, pada gambar 10 terlihat perbedaan umur masyarakat yang berkumpul di kawasan Petemon. Berdasarkan pengamatan dan wawancara dan pengamatan, pada generasi kedua mulai muncul pilihan dimana beberapa penduduk asli tetap tinggal, namun terdapat juga penduduk yang memilih untuk pindah (gambar 11). Walaupun demikian, penduduk asli generasi 1 dan 2 tetap tinggal di sana, serta secara umum terdapat pewaris dari salah satu keturunan generasi 2 (generasi 3) yang akan tetap tinggal untuk melestarikan warisannya. Sebagai rumah masa kecil, pada hari tertentu, seperti Hari Raya, kampung ini menjadi tempat berkumpul sanak saudara sehingga pengalaman masa kecil dahulu tetap terjaga bagi sebagian orang yang mengunjungi kembali daerah ini.

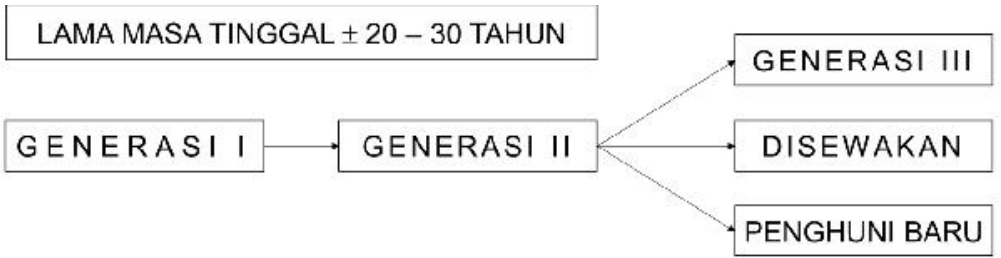

Gambar 11. Bagan Generasi yang Tinggal di Kawasan Petemon

\subsection{Analisis Faktor Fasilitas Sosial}

Interaksi yang dilakukan manusia di dalam suatu ruang dapat terjadi antara manusia - tempat; manusia - manusia. Place attachment berkaitan dengan even yang memiliki periode perayaan masing masing. Pada studi interkultural, festival, perayaan, dan aktivitas yang bertujuan merupakan salah satu faktor penting dalam mempromosikan kultur pada suatu tempat.
Pada Kawasan Petemon seperti yang terlihat di gambar 12, interaksi secara umum dapat terjadi di jalan sebagai locus kehidupan, mengingat kawasannya yang padat bangunan tidak menyediakan ruang luar yang cukup. Selain itu pemanfaatan halaman sebagai ruang publik juga nampak disana. Pada gambar 12 berikut tampak anak-anak yang memanfaatkan jalan sebagai ruang interaksi dengan adanya atraksi "topeng monyet" yang dilakukan di tepi jalan dan disaksikan bersama-sama yang ditandakan dengan lingkaran berwarna kuning. 


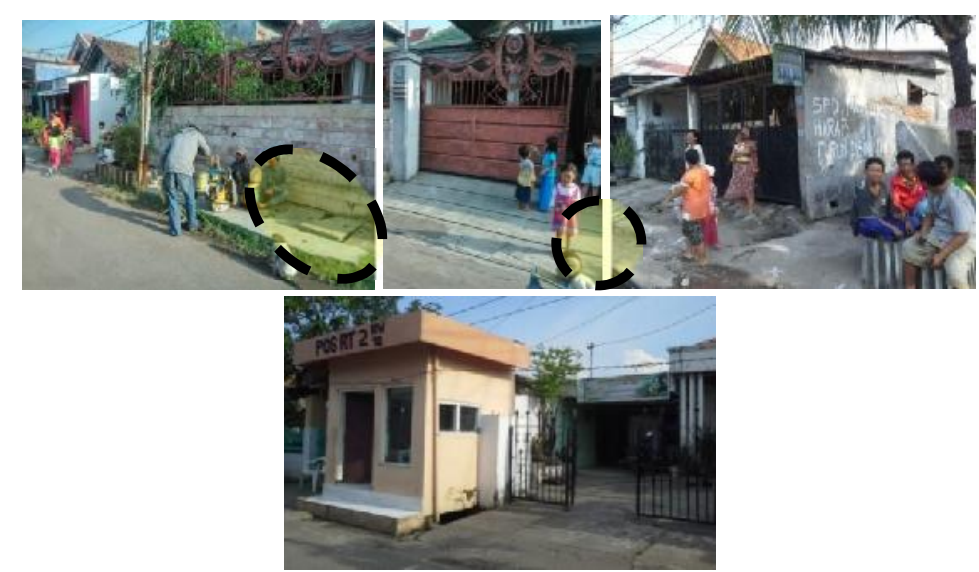

Gambar 12. Jalan Petemon sebagai Locus Kehidupan dan balai di kawasan Petemon

Selain penggunaan jalan dan halaman, pada Kawasan Petemon juga terdapat balaibalai yang dapat berfungsi sebagai tempat pertemuan rutin. Balai-balai ini didirikan diatas saluran yang telah ditutup untuk mengatasi keterbatasan lahan. Sebagai perkampungan, warga kawasan ini masih memiliki karakter yang "guyub", hal ini dibuktikan dengan kegiatan rutin mingguan/bulanan/tahunan yang diadakan oleh organisasi setempat, seperti karang taruna, PKK, serta RT maupun RW. Selain itu diadakan juga pasar kaget dan bazaar pada hari-hari tertentu.

\subsection{Analisis Faktor Kepuasan akan Suatu Tempat}

Kepuasan akan suatu tempat berkaitan dengan kualitas, keamanan secara fisik, sosial, dan emosional. Place attachment berkembang karena terdapat ekspetasi terhadap suatu tempat dari pengalaman akan tempat yang sebelumnya. Kepuasan tersebut memiliki faktor seperti fasilitas, adaptasi, keberlanjutan, karakteristik dan manajemen visual, nilai ekonomi, persamaan visi antar penduduk, latar belakang, fitur arsitektural maupun kota, dan ruang - ruang sosial. 


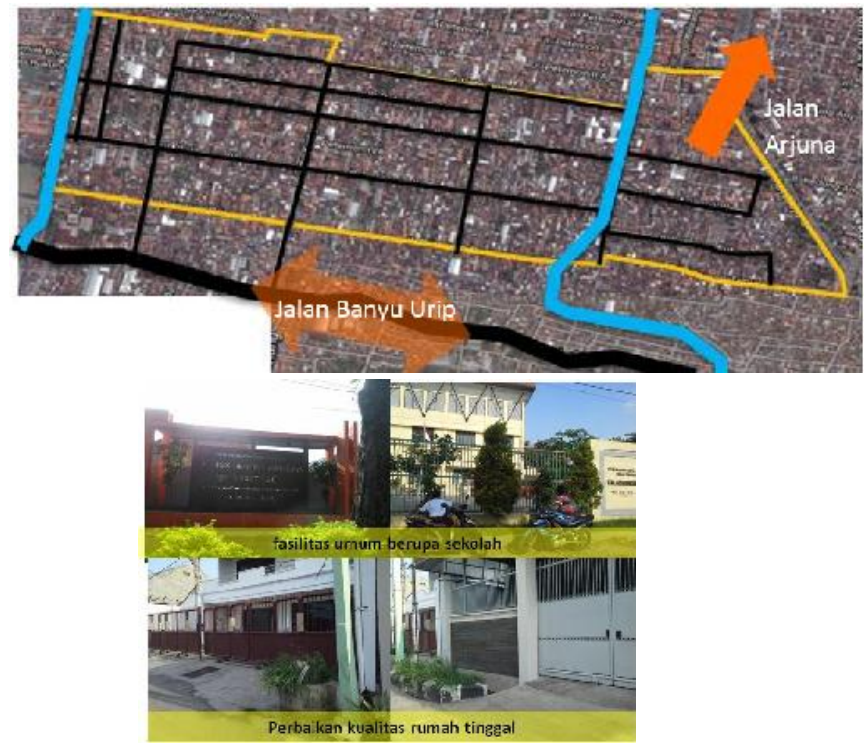

Gambar 13. Aksesibilitas Kawasan Petemon (kiri) dan bangunan di kawasan Petemon (kanan)

Pada gambar 13 dilokasi permukiman dekat dengan tempat bekerja dan mudah diakses yang diindikasikan dengan jalan Banyu Urip untuk akses ke Surabaya Barat, dan jalan Arjuna untuk akses menuju Surabaya Utara serta Surabaya Pusat. Pada kawasan ini tampak beberapa fasilitas seperti sekolah. Selain itu, terdapat peningkatan kualitas lingkungan dengan pavingisasi, perbaikan kualitas rumah tinggal, serta perkembangan kawasan perdagangan dan jasa di kawasan peri-peri permukiman. Hal ini menandakan kepuasan penghuni akan kawasan maupun pemenuhan ekspetasi penghuni yang menguatkan ikatan antara individu dengan tempatnya.

\subsection{Place Attachment}

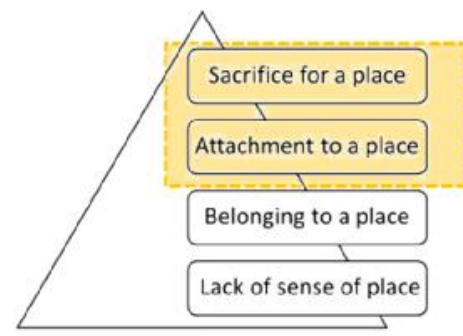

Gambar 14. Tahapan Keterikatan terhadap tempat permukiman Petemon

Dalam permukiman Petemon, terlihat upaya memperbaiki lingkungan fisik yang cukup ekstreme serta terdapat indikasi akan kepuasan warga terhadap tempat sehingga membentuk suatu budaya bermukim sesuai dengan perilaku, kognitif dan emosi. Hal ini menunjukkan bahwa dalam tingkatan keterikatan terhadap tempat, kampung dan 
masyarakat kampung Petemon berada pada tingkat sacrifice to a place seperti gambar 14 diatas. Menurut Newell (2018) hal ini diartikan sebagai komitmen paling tinggi terhadap suatu tempat. Masyarakat yang bermukim didalamnya rela mengorbankan atribut penting maupun nilai-nilai seperti kesejahteraan, kebebasan, atau kehidupan itu sendiri. Dikenali pula bahwa melalui aspek kognitifnya, warga permukiman petemon juga masuk kedalam kategorisasi attachment to a place, karena masyarakat sudah mampu mengidentifikasi tujuan dari tempat tersebut, terdapat integrasi yang menyebabkan timbulnya rasa kebersamaan untuk meraih tujuan tersebut. Oleh karena itu mereka memiliki keterikatan yang kuat pada masing - masing tempat tersebut.
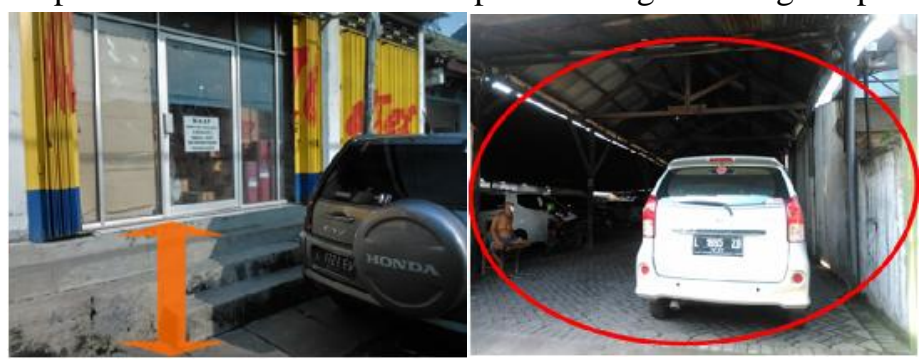

Gambar 15. Integrasi kawasan Petemon terhadap kondisi ekstrem pada lingkungannya

Pada gambar 15 terlihat proses adaptasi habitat terhadap permukiman Petemon yang dindikasikan dengan naiknya tinggi lantai bangunan (panah oranye) dari jalan, keberadaan parkir kendaraan bermotor komunal (lingkaran merah) untuk mengakomodasi kebutuhan transportasi.
Melalui kajian yang telah dilakukan sebelumnya maka terlihat potensi dan masalah yang nampak pada permukiman Petemon Surabaya, bisa dilihat pada tabel 1 dibawah ini.

Tabel 1. Potensi dan Masalah pada Permukiman Petemon Surabaya

\section{POTENSI}

1. Keberagaman user

2. Keaktifan warga dalam berkomunitas (kontribusi terhadap lingkungannya)

3. Adaptasi lingkungan tanggap banjir, berupa konsepsi awal masyarakat

4. Pengembangan kawasan perdagangan dan jasa dengan lokasi potensial dekat dengan pusat kota

\section{MASALAH}

1. Keterbatasan ruang terbuka sebagai ruang publik

2. Penutupan saluran sebagai upaya penyediaan lahan ruang publik

3. Timbulnya prasangka negatif terhadap lingkungan

4. Penumpukan volume lalu lintas sebagai dampak perkembangan kawasan sebagai penghubung pusat-selatan kota

5. Penanganan kawasan tanggap banjir saat ini hanya dilakukan secara parsial 


\section{KESIMPULAN}

Keterikatan pada tempat merupakan hal yang lebih dari sekedar perjalanan emosi atau pengalaman kognitif individu/kelompok akan tempat maupun hubungannya. Pemahaman tempat didasarkan pada ikatan emosional seseorang terhadap suatu tempat, lebih lanjut dinyatakan bahwa ikatan tersebut dapat berawal dari pengalaman nyata pada tempat tersebut atau dari keabstrakan lingkungan alamnya, sebagai hasil dari proses simbolis pada suatu kurun waktu tertentu.

Permukiman Petemon terletak di UP Wonokromo, dengan lokasi strategis dekat dengan Jalan Banyu Urip yang menghubungkan bagian selatan-barat Kota Surabaya dengan pusat Kota Surabaya. Kondisinya sebagai permukiman padat huni serta kawasan rawan bencana banjir tidak lantas membuat penduduknya pindah dari kawasan tersebut hingga beberapa generasi. Hal ini menunjukkan indikasi adanya keterikatan pada tempat (place attachment) yang kuat antara masyarakat dengan permukiman Petemon.

Keterikatan pada tempat di Permukiman Petemon diidentifikasi dari 7 faktor, yaitu:

1. Faktor fisik : adanya modifikasi hunian untuk menyesuaikan kondisi lingkungan (bangunan ditinggikan, parkir komunal);

2. Faktor sosial : aktivitas sehari-hari masyarakat di ruang publik; masyarakat merasa aman dan memiliki permukiman;

3. Faktor kultural : masyarakat multietnis yang menetap dan membentuk tradisi bersama yang baru, misalnya kampung tematik (kampung lontong);

4. Faktor Individu : adanya pilihan individu untuk tetap tinggal maupun pindah dan menyewakan tempat tinggalnya;

5. Waktu, memori, dan pengalaman: masyarakat yang tinggal rata-rata telah menetap 20-30 tahun, selama 3 generasi;

6. Fitur untuk berinteraksi dan aktivitas: jalan sebagai locus kehidupan serta agenda kegiatan rutin harian/mingguan/bulanan/tahunan

masyarakat;

7. Kepuasan akan suatu tempat : munculnya fasilitas-fasilitas umum, serta upaya perbaikan kualitas hunian.

Berdasarkan kajian diatas dapat diidentifikasikan bahwa habitat selection maupun proses adaptasi habitat di kawasan Petemon terjadi di permukiman Petemon. Dimana permukiman Petemon memiliki seluruh tujuh faktor tersebut dan menempatkan masyarakat Petemon pada hiearki place attachment tertinggi yaitu sacrifice to a place. Fenomena unik ini membuat masyarakat Petemon mampu bertahan dan beradaptasi pada suatu lingkungan yang rawan bencana banjir.

70 Jurnal Teknik WAKTU Volume 17 Nomor 01 - Januari 2019 - ISSN: 1412:1867 


\section{UCAPAN TERIMA KASIH}

Penelitian ini telah mendapatkan dukungan dari Dekan, Ketua Program Studi
Perencanaan Wilayah dan Kota Fakultas Teknik Sipil dan Perencanaan, Universitas PGRI Adi Buana Surabaya.

\section{DAFTAR PUSTAKA}

BPS. 2014. Kecamatan Sawahan dalam Angka 2014

BPS. 2015. Kecamatan Sawahan dalam Angka 2015

BPS. 2016. Kecamatan Sawahan dalam Anzahgka 2016

BPS. 2017. Kecamatan Sawahan dalam Angka 2017

Hashemnezhad, Hashem. (2013). Sense of Place and Place Attachment, A Comparative Study. International Journal of Architecture and Urban Development.

Hashemnezhad et al (2013) Comparison the concepts of sense of place and attachment to place in Architectural Studies. Malaysia Journal of Society and Space 9 issue 1. Pp. $107-117$

Hidalgo, M. C. and B. Hernandez (2001). "Place Attachment: Conceptual and Empirical Questions." Journal of Environmental Psychology 21(3): 273-281.

Husain, Sarkawi B. (2016). Banjir, Pengendaliannya, dan Partisipasi Masyarakat di Surabaya, 1950 -1976. Jurnal Masyarakat dan Budaya. Volume 18 No. 1 Tahun 2016

Katherina, Luh Kitty. (2017). Dinamika Pertumbuhan Penduduk dan Kejadian Banjir di Kota: Kasus Surabaya. Jurnal Kependudukan Indonesia Vol. 12 No. 2 Desember 2017. LIPI, Jakarta

Rapoport, Amos. (2018). Some Further Thoughts On Culture and Environment. Archnet-IJAR, International Journal of Architectural Research, Volume 2 Issue 1 March 2009 (16-39)

Silas, Johan. Ernawati, Rita. (2013). Liveability of Settlements by People in the Kampung of Surabaya. Proceedings of the 19th International CIB World Building Congress: Construction and Society, QUT, Brisbane

Newell, Robert. (2018). From sense of place to visualization of place: examining people-place relationships for insight on developing geovisualizations. Heliyon Volume 4, Issue 2. Elsevier Ltd.

Stedman RC (2003). Is it really just a social construction: the contribution of the physical environment to sense of place. Society and Natural Resources 16(8):671-685

Zakiyah. (2017). Ketika Hujan Deras, Banjir dan Macet Menerpa Kota. Liputan6.com. Surabaya. Retrieved from https://www.liputan6.com/regional/read/3174852/ketika-hujan-deras-banjirdan-macet-menerpa-kota-surabaya

Zubaidi, Fuad. (2007). Pengaruh timbal balik perilaku dan ruang disadur dari http://arsitadulako.blogspot.com/2007/05/pengaruh-timbal-balik-dan-ruang.html tanggal 15 April 2017 pukul 4.15 WIB 